\title{
Development of a heptaplex PCR assay for identification of Staphylococcus aureus and CoNS with simultaneous detection of virulence and antibiotic resistance genes
}

\author{
Charles Emeka Okolie ${ }^{1,2^{*}}$, Karl G. Wooldridge ${ }^{1}$, David P.J. Turner' ${ }^{1}$ Alan Cockayne ${ }^{1}$ and Richard James ${ }^{1}$
}

\begin{abstract}
Background: Staphylococcal toxicity and antibiotic resistance (STAAR) have been menacing public health. Although vancomycin-resistant Staphylococcus aureus (VRSA) is currently not as widespread as methicillin-resistant $S$. aureus (MRSA), genome evolution of MRSA into VRSA, including strains engineered within the same patient under anti-staphylococcal therapy, may build up to future public health concern. To further complicate diagnosis, infection control and anti-microbial chemotherapy, non-sterile sites such as the nares and the skin could contain both S. aureus and coagulase-negative staphylococci (CoNS), either of which could harbour mecA the gene driving staphylococcal methicillin-resistance and required for MRSA-VRSA evolution.
\end{abstract}

Results: A new heptaplex PCR assay has been developed which simultaneously detects seven markers for: i) eubacteria (16S rRNA), ii) Staphylococcus genus (tuf), iii) Staphylococcus aureus (spa), iv) CoNS (cns), v) Panton-Valentine leukocidin $(p v)$, vi) methicillin resistance (mecA), and vii) vancomycin resistance (vanA). Following successful validation using 255 reference bacterial strains, applicability to analyse clinical samples was evaluated by direct amplification in spiked blood cultures $(n=89)$ which returned $100 \%$ specificity, negative and positive predictive values. The new assay has LoD of $1.0 \times 10^{3} \mathrm{CFU} / \mathrm{mL}$ for the $16 \mathrm{~S}$ rRNA marker and $1.0 \times 10^{4} \mathrm{CFU} / \mathrm{mL}$ for six other markers and completes cycling in less than one hour.

Conclusion: The speed, sensitivity (100 \%), NPV (100 \%) and PPV (100 \%) suggest the new heptaplex PCR assay could be easily integrated into a routine diagnostic microbiology workflow. Detection of the cns marker allows for unique identification of CoNS in mono-microbial and in poly-microbial samples containing mixtures of CoNS and S. aureus without recourse to the conventional elimination approach which is ambiguous. In addition to the SA-CoNS differential diagnostic essence of the new assay, inclusion of vanA primers will allow microbiology laboratories to stay ahead of the emerging MRSA-VRSA evolution. To the best of our knowledge, the new heptaplex PCR assay is the most multiplexed among similar PCR-based assays for simultaneous detection of STAAR.

Keywords: Differential diagnosis, tuf gene polymorphism, Mixed infection, Therapy-refractory

\footnotetext{
* Correspondence: okolie.charles@lmu.edu.ng

${ }^{1}$ Centre for Healthcare Associated Infections, Centre for Biomolecular

Sciences Building, The University of Nottingham, University Park, Nottingham NG7 2RD, UK

${ }^{2}$ Centre for Advanced Research and Development, Landmark University, Omu-Aran, Kwara State, Nigeria
}

\section{() Biomed Central}




\section{Background}

Accumulation of genes encoding staphylococcal toxigenicity and antibiotic-resistance (STAAR) in the genus Staphylococcus is well documented. The evolution of STAAR factors in Staphylococcus aureus has resulted to the emergence of strains associated with infections recently described as life-threatening and refractory to therapy [1, 2]. Some bacterial factors are not easily detected by conventional agar-based bacteriological cultures. PCR-based assays are capable of identifying the genetic capacity for STAAR without the influence of variability in gene expression [3] and are preferred for speed and sensitivity.

Genome evolution is responsible for the emergence of strains harbouring STAAR factors some of which pose diagnostic challenges. For detection of $m e c A$-encoded staphylococcal methicillin resistance, several investigators have reported multiplex PCR assays which accurately detected mecA gene and correlated well with the oxacillin phenotype $[4,5]$. Since $S$. aureus and coagulasenegative staphylococci (CoNS) harbor the mecA gene in common, Huletsky and colleagues highlighted the need for a discriminatory assay capable of identifying the cohabitation of $S$. aureus and coagulase-negative staphylococci (CoNS) especially in non-sterile sites such as the nares and the skin [6]. They discriminated S. aureus from CoNS by detecting DNA from the staphylococcal cassette chromosome (SCC) using oligonucleotides which hybridised to the $S$. aureus open reading frame encoding unknown function $(\operatorname{orf} X)$ [6]. However, commercial assays inspired by the orf $X$ oligos attracted numerous reports of assay failure because some SCC types which lacked the $m e c A$ gene were misidentified as MRSA [7, 8].

Basically, there are PCR-based assays for species identification of CoNS [9-11]. However, as the taxa of clinically relevant member species of the genus Staphylococcus continues expanding $[12,13]$, no species-specific assay has been capable of detecting all the species in one PCR tube. Consequently, PCR-based assays for identification of CoNS have relied on elimination based on the absence or non-detection of $S$. aureus markers such as coa, nuc, spa or femA [14]. Although the elimination approach may yield good results for mono-microbial infections, lack of a unique marker for CoNS renders such assays unreliable for identification of CoNS in poly-microbial samples containing both $S$. aureus and CoNS.

Recently the genomes of some MRSA strains evolved further. As a result of the acquisition of the vanA gene from enterococci vancomycin-resistant $S$. aureus (VRSA) evolved among MRSA strains $[15,16]$. The recent emergence of VRSA in Portugal [17] may lead to the spread of VRSA in Europe and beyond. Furthermore, the increase in the incidence of MRSA strains belonging to the CC5 clade associated with hospital MRSA-VRSA evolution in different parts of the globe [18], including the case of the Brazilian patient whose own bloodstream vancomycin-susceptible MRSA (VS-MRSA) acquired vanA during antibiotic therapy and became VRSA [19] and the $13.3 \%$ incidence of VRSA in some hospitals [20], collectively point to the hazardous capacity of this lineage, suggesting that the genetic engineering and dissemination of community associated MRSA containing vanA could escalate to a serious public health concern. The recent report of $46.2 \%$ VRSA among MRSA strains isolated in chickens [21] further suggests that VRSA constitutes an impending threat to public health.

In line with the identified need for multiplex PCR assays capable of detection of multiple microbes or multiple genetic markers within the same PCR tube [22], we aimed to develop a multiplex PCR assay. Our experiments resulted in a new heptaplex PCR assay which simultaneously detected seven DNA markers for: (i) $16 \mathrm{~S}$ rRNA (ubiquitous bacteria), (ii) spa (S. aureus), (iii) tuf (the genus Staphylococcus spp.), (iv) cns (CoNS), (v) pvl (PVL virulence factor), (vi) mecA (methicillin resistance), and (vii) vanA (vancomycin resistance).

\section{Methods}

\section{Bioethics and biosafety}

The Research Committee, University of Nottingham, approved this study. Human-associated materials, including clinical bacterial isolates and blood cultures, were de-identified so they could not be tracked back to the patients. Many of the bacterial strains used in this study were obtained from the Network for Antibiotic Resistance in Staphylococcus aureus (NARSA) Strain Repository (www.narsa.net), some of which are putatively multi-resistant and/or highly virulent. An enhanced level 2 (BSL2+) suite was provided for storage and work on such potentially hazardous agents. Local strains were manipulated completely in the general (BSL2) laboratory space.

\section{Bacterial strains and bacteriological media used for this study}

All bacteriological media and consumables used for this study were purchased from Oxoid, Basingstoke, UK. Bacterial strains $(n=255)$ were sub-cultured from storage $\left(-80{ }^{\circ} \mathrm{C}\right)$ into brain heart infusion $(\mathrm{BHI})$ broth and plated out on BHI agar. From BHI plates, a 0.5 McFarland standardised inoculum was generated for each isolate and used for gene detection and phenotypic tests. Reference type cultures $(\mathrm{n}=53)$ comprising staphylococcal strains were used to validate the 7 genetic markers targeted by the new heptaplex PCR assay. Identification of the sources of the type cultures along with the numbers of strains belonging to S. aureus and CoNS are 
indicated (Additional file 1). Local clinical staphylococcal strains $(n=124)$ were collected from the hospitals in the Nottingham area (August 2003 - December 2004). They were previously characterized by the Queen's Medical Centre (QMC) Nottingham NHS microbiology laboratory and de-identified by Dr. Richard Spence who used them for DNA microarrays [23]. CoNS strains $(n=31)$ donated by Nottingham University's Centre for Biomolecular Sciences (CBS) researchers who previously characterized them as $S$. auricularis (2), S capitis (2), $S$. caprae (2), S. chromogenes (2), S. cohnii (2), S. epidermidis (2), S. hemolyticus (1), S. hominis (2), S. hyicus (2), S. intermedius (2), S. lugdunensis (1), S. saprophyticus (3), S. sciuri (2), S. simulans (2), S. warneri (2) and S. xylosus (2) were included. Other (non-staphylococcal) bacteria $(\mathrm{n}=47)$ previously characterized and de-identified by CBS researchers including strains of Escherichia coli, Pseudomonas spp., Klebsiella spp., Aeromonas spp., Salmonella spp., Citrobacter spp., Proteus spp., and Group A streptococci (GAS) were also used.

\section{Preparation of bacterial DNA}

Preparation of bacterial cell lysates from NARSA strains followed a heating and centrifugation method reported elsewhere [24]. Bacterial DNA was obtained from spiked blood culture by Triton X-100 cell lysis method [25]. Following bacterial cell lysis step, the DNA-rich supernatant was transferred into a fresh $0.5 \mathrm{~mL}$ Eppendorf tube for PCR in the general (BSL2) laboratory. The lysis step was waived for local strains: bacterial colonies were directly picked and used in PCR. Similarly, broths were applied directly into PCR as previously evaluated in our laboratory and found reliable [24].

\section{Development and optimization of the heptaplex PCR}

The $s p a, p v l$ and $m e c A$ primers were originally published by Nakagawa et al. [26]; they reliably detected $s p a, p v l$ and $m e c A$ in our laboratory [24]. The cns and 16S rRNA primers were copied from a recently published pentaplex real-time PCR assay [27]. Following other reports [28, 29], multiple alignments in clustalW (www.ebi.ac.uk/ tools/clustalW) were used to design the primers targeting tuf and vanA. The greater discriminatory power of staphylococcal tuf over $16 S$ rRNA for identification of CoNS has been reported [30] and was exploited in this assay. To supply all the seven key genetic loci targeted in the new PCR, a mixed infection model comprising 3 staphylococcal strains was made up. The strains used to generate the mixed infection model were: i) vancomycinresistant $S$. aureus strain VRS1 (16S, tuf, spa, vanA and mecA), ii) PVL-positive MSSA strain NRS157 (16S, tuf, $s p a$, and $p v l$ ), and iii) methicillin susceptible CoNS strain S. lugdunensis NCTC12217 (16S, tuf, and cns). Bacterial cell lysates $(10 \mu \mathrm{L})$, broth cultures or direct bacterial colonies were used as template for PCR in a $40 \mu \mathrm{L}$ volume. Beginning with the five primer sets recently reported in our laboratory [27] and in a stepwise manner, the number of markers detected was scaled up to seven by adding two new primer sets targeting tuf and vanA genes. Following recent reports [31, 32], Candida albicans $(\mathrm{n}=4)$ were used as non-bacterial negative control template while the $16 S$ rRNA marker for ubiquitous bacteria served as a positive control in every PCR reaction containing bacterial DNA. The PCR was performed using Eppendorf mastercycler (Eppendorf, Hamburg, Germany). The cycling conditions were copied from a recent pentaplex real-time PCR assay [27]. Briefly, an initial single cycle for 5 minutes at $94{ }^{\circ} \mathrm{C}$ was followed by 40 cycles consisting of 15 seconds at $94{ }^{\circ} \mathrm{C}$ (denaturation) and 5 seconds at $60{ }^{\circ} \mathrm{C}$ (amplification) with one final run of 30 seconds at $72{ }^{\circ} \mathrm{C}$ (final polymerase extension). PCR optimization followed recent strategies [33, 34]: hot-start PCR was performed in which Taq DNA polymerase was withheld until the cycler showed the reaction temperature was above $85{ }^{\circ} \mathrm{C}$. The PCR mixture contained $0.500 \mathrm{mM}$ of dNTPs, $10 \mathrm{U}$ of Taq DNA polymerase (New England Biolabs, UK) and thermopol buffer ( $\mathrm{pH} 8.8$ at $\left.25{ }^{\circ} \mathrm{C}, 5 \mu \mathrm{L}\right)$ comprising: $20 \mathrm{mM}$ Tris- $\mathrm{HCl}, 10 \mathrm{mM}\left(\mathrm{NH}_{4}\right)_{2} \mathrm{SO}_{4}, 10 \mathrm{mM} \mathrm{KCl}, 2 \mathrm{mM} \mathrm{MgSO}_{4}$, $0.1 \%$ Triton X-100. Bacterial cell lysates $(10 \mu \mathrm{L})$ from spiked blood cultures were used as template for PCR in a $40 \mu \mathrm{L}$ volume. PCR amplicons were resolved by electrophoresis ( $200 \mathrm{~V}, 3$ hours) in $4 \%$ agarose gel containing Ethidium bromide $(0.5 \mathrm{~g} / \mathrm{L})$ and visualised in UV transilluminator (UVP, UK). PCR products were purified from agarose gels using GenElute ${ }^{\mathrm{Tw}}$ (Sigma, UK). Sequencing reactions were prepared by BigDye ${ }^{\mathrm{mt}}$ protocol (AppliedBiosystems, USA) and analysed using ABI Prism 310 Genetic analyser (AppliedBiosystems, USA). Identity of PCR amplicons was confirmed by BLAST search on NCBI databases (http://blast.ncbi.nlm.nih.gov/Blast.cgi). The limit of detection (LoD) was determined by ten-fold serial dilutions performed on a 0.5 McFarland inoculum. Following isolation on BHI plates, Gram staining was performed to differentiate Gram-positive from Gram-negative bacteria. Tube coagulase test (TCT) was used to differentiate $S$. aureus from CoNS. Oxacillin salt agar screen (OSAS) containing $4 \% \mathrm{NaCl}$, reported elsewhere as most reliable especially for CoNS $[35,36]$ was performed according to the agar dilution methods recommended by the CLSI [37]. For identification of staphylococcal vancomycin phenotype, vancomycin agar screen (VAS) was performed and interpreted according to CLSI [38]. Following CLSI recommendations [38, 39], Mueller-Hinton agar was used in disk diffusion method to screen for: (i) oxacillin-resistance using $1.0 \mu \mathrm{g}$ oxacillin disc; and (ii) vancomycin-resistance using $6.0 \mu \mathrm{g}$ vancomycin disc. For assay reproducibility, positive and negative characters were inferred upon the agreement of results 
obtained from four or more repeated gene detection and phenotypic tests performed on different days: the same 0.5McFarland inoculum prepared for PCR was used for phenotypic tests including colony counts. Aside from gene amplification from the bacterial strains performed directly on the frozen material, directly from $\mathrm{BHI}$ broth and directly from discrete colonies grown on BHI agar, the capacity of the new assay to detect the seven genetic markers directly from clinical samples was studied using spiked blood cultures containing bacterial strains in mono-microbial and poly-microbial models. Spiking of blood cultures followed a recent report for direct identification of staphylococci from blood culture material [40] with modifications. Briefly, the de-identified clinical blood culture bottles which have been cultured for 1 week and remained negative, derived from routine diagnostic microbiology, were spiked and then tested by PCR. Detected sequences were analysed as negative predictive values (NPV) and positive predictive values (PPV) according to recent CLSI guidelines [41].

\section{Results and discussion}

Multiple alignments in clustalW enabled the identification of loci within the nucleotide sequences of target genes for suitable primer hybridization. Although the detection of tuf gene as a marker for the identification of the genus Staphylococcus is well documented [42], the new heptaplex PCR is the first end-point PCR-based assay which demonstrated the discriminatory power of some polymorphic regions of the staphylococcal tuf for unique detection of CoNS. This allows the simultaneous detection of markers specific for S. aureus and CoNS within the same PCR tube without recourse to the conventional elimination approach thus allowing mixtures of $S$. aureus and CoNS to be identified without cumber and ambiguity.

Bioinformatic analysis initially identified AAGACTG CACGTTCAGGCTC, a 20-letter oligonucleotide sequence as the vanA forward primer. Though the former
vanA forward primer generated a vanA positive amplicon with very high specificity in a 235 bp monoplex PCR [29], it interfered with other reactions. Replacement of the interfering primer with the current vanA forward primer listed in Table 1 generated a $111 \mathrm{bp}$ amplicon without interference thus allowing the simultaneous amplification of all the seven markers targeted by the new heptaplex PCR (Fig. 1).

The 111bp vanA marker was amplified from all (100\%) VRSA reference strains listed in Additional file 1. Upon these findings, it was inferred that useful as in silico bioinformatics work-up is in PCR primer prediction, wet experimentation is still needed to confirm the reliability of PCRs developed from such predictions. This is particularly important as very powerful bioinformatics tools are entering the oligo-design research arena, including those capable of aligning nearly a million sequences of the bacterial 16S rRNA gene [31]. Also, the lack of amplification in the negative control PCRs containing C. albicans template (Fig. 1 lane 2 and Fig. 2 lanes 5 and 11) further attests to the specificity of the new assay which is illustrated using numerous reference strains and their combinations (Fig. 2).

The optimal concentration of the oligonucleotide primers which yielded clearly detectable amplification products in the new heptaplex PCR assay were found to be $0.50 \mu \mathrm{M}$ for cns and $0.75 \mu \mathrm{M}$ for the other six targets.

Gene detection in spiked blood cultures, including mono- and poly-microbial cultures, showed the new assay detected all the seven targets (Additional file 2). Additional file 2 also shows that all the expected genes were correctly detected with $100 \%$ specificity, NPV, and PPV thus enabling assignment of MSSA, PPMSSA, MRSA, PPMRSA, MSCoNS, MRCoNS, and VRSA. No PCR product was generated from the eukaryotic template, C. albicans, used as PCR negative control, a finding which supports its use as negative control for bacterial PCRs [31, 32].

The 111 bp vanA marker was not detected in the local clinical isolates. Thus the new assay corroborates the

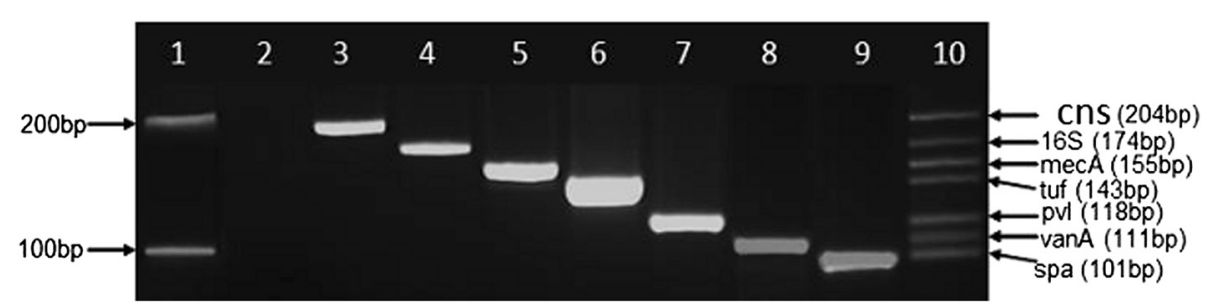

Fig. 1 Development of the new heptaplex PCR showing the amplification of single and multiple DNA markers. Lane 1: 100 bp DNA Marker (New England Biolabs, NEB, UK) with upper band [200 bp] and lower band [100 bp], Lane 2: PCR negative control [Candida albicans], Lane 3: coagulase-negative staphylococcus marker [cns, 204 bp], Lane 4: bacterial 16S rRNA marker [16S, 174 bp], Lane 5: mecA marker [mecA, 155 bp], Lane 6: staphylococcus genus translation elongation factor marker [tuf, 143 bp], Lane 7: Panton-Valentine leukocidin marker [pvl, 118 bp], Lane 8: Vancomycin resistance marker [vanA, 111 bp], Lane 9: staphylococcal protein A marker [spa, 101 bp], Lane 10: Heptaplex PCR showing all seven markers (cns, 16S, mecA, tuf, pvl, vanA and spa) from top to bottom respectively 


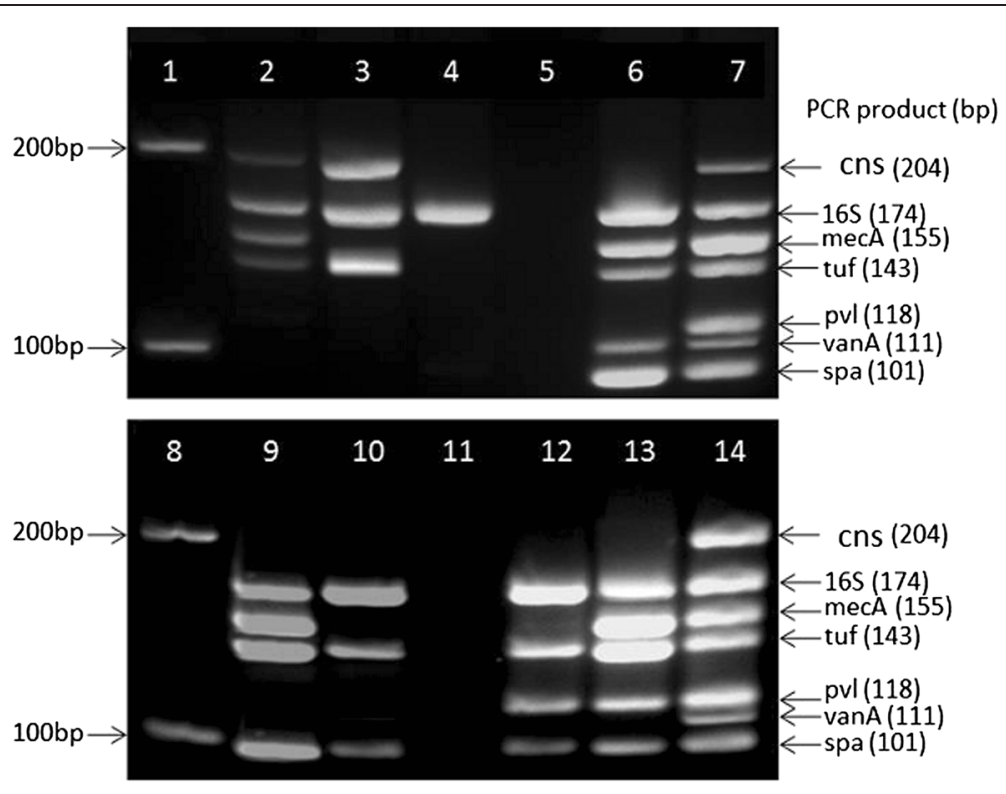

Fig. 2 Validation of the new heptaplex PCR assay. Lanes 1 and 8: 100 bp DNA ladder (NEB, UK); Lane 2: MRCoNS strain S. epidermidis NRS8 showing the markers cns, 16S, mecA, and tuf; Lane 3: Nottingham local MSCoNS showing the markers cns, 16S, and tuf; Lane 4: Group A Streptococcus showing only the 16S marker for bacterial 16SrRNA gene; Lanes 5 and 11: PCR negative control (Candida albicans); Lane 6: VRSA strain VRS1 showing the markers 16S, mecA, tuf, vanA, and spa; Lanes 7 and 14: mixed template comprising vancomycin-resistant S. aureus strain VRS1, methicillin susceptible CoNS strain S. lugdunensis NCTC12217 and PVL-positive MSSA strain NRS157 and showing all the seven markers (cns, 16S, mecA, tuf, pvl, vanA, and spa); Lane 9: PVL-negative MRSA strain Sanger252 showing the markers 16S, mecA, tuf, and spa; Lane 10: PVL-negative MSSA strain Sanger476 showing the markers 16S, tuf, and spa; Lane 12: PVL-positive MSSA strain NRS157 showing the markers 16S, tuf, pvl, and spa; Lane13: PVL-positive S. aureus strain USA400 (MW2) showing the markers 16S, mecA, tuf, pvl, and spa

QMC phenotypic data for the local clinical staphylococci in agreement with the fact that they were uniformly susceptible to vancomycin by the VAS used to support vanA PCR in this study. However, one of the local strains showed discrepancy between the QMC data and gene detection by the new assay. Previously identified as methicillin susceptible Staphylococcus epidermidis (MSSE), the strain in question yielded PCR products for $16 S$, tuf, mecA and cns which together characterize MRCoNS (typical of Fig. 2 lane 2). The oxacillin $1 \mu \mathrm{g}$ disk diffusion method identified the strain as MSCoNS. Interestingly, there was growth on the $0.5 \mathrm{mg} / \mathrm{L}$

Table 1 Oligonucleotide primers used in the heptaplex PCR assay

\begin{tabular}{|c|c|c|c|c|}
\hline Target DNA & Amplicon size (bp) & Primer Identity & Primer sequence $5^{\prime} \rightarrow 3^{\prime}$ & Reference \\
\hline \multirow[t]{2}{*}{ cns } & \multirow[t]{2}{*}{204} & cns-1 & TATCCACGAAACTTCTAAAACAACTGTTACT & \multirow[t]{2}{*}[27]{} \\
\hline & & cns-2 & TCTTTAGATAATACGTATACTTCAGCTITGAATTT & \\
\hline \multirow[t]{2}{*}{$16 \mathrm{~S}$ rRNA } & \multirow[t]{2}{*}{174} & $16 S-1$ & CTAGTAATCGCGGATCAGCAT & \multirow[t]{2}{*}[27]{} \\
\hline & & $16 S-2$ & GATACGGCTACCTTGTTACGACTT & \\
\hline \multirow[t]{2}{*}{ mecA } & \multirow[t]{2}{*}{155} & mecA-1 & TGGTATGTGGAAGTTAGATTGGGAT & \multirow[t]{2}{*}{ [26] } \\
\hline & & mecA-2 & CTAATCTCATATGTGTTCCTGTATTGGC & \\
\hline \multirow[t]{2}{*}{ tuf } & \multirow[t]{2}{*}{143} & tuf-1 & TACCAGCATTAGTAGTATTCTTAAACAAAGTTG & \multirow[t]{2}{*}{ This stud } \\
\hline & & tuf-2 & TGCTGAACCAGCGATTACAG & \\
\hline \multirow[t]{2}{*}{$\mathrm{pvl}$} & \multirow[t]{2}{*}{118} & pvl-1 & TTACACAGTTAAATATGAAGTGAACTGGA & \multirow[t]{2}{*}{ [26] } \\
\hline & & $\mathrm{pvl}-2$ & AGCAAAAGCAATGCAATTGATG & \\
\hline \multirow[t]{2}{*}{$\operatorname{van} A$} & \multirow[t]{2}{*}{111} & $\operatorname{van} A-1$ & GCTGTGAGGTCGGTTGTG & \multirow[t]{2}{*}{ This stud) } \\
\hline & & $\operatorname{van} A-2$ & GCTCGACTTCCTGATGAATACG & \\
\hline \multirow[t]{2}{*}{ spa } & \multirow[t]{2}{*}{101} & spa-1 & CAGCAAACCATGCAGATGCTA & \multirow[t]{2}{*}{ [26] } \\
\hline & & spa-2 & CGCTAATGATAATCCACCAAATACA & \\
\hline
\end{tabular}


oxacillin plate while increasing concentrations inhibited the strain.

For taxonomical purposes, the relevance of speciesspecific PCR-based assays cannot be undermined though. However, owing to the continuing expansion in the taxa of clinically relevant member species of the genus Staphylococcus $[12,13]$, there is yet no speciesspecific PCR-based assay capable of identifying all clinically relevant CoNS in one PCR tube. This puts a limitation on species-specific PCR-based assays. To circumvent this, the new heptaplex PCR assay identifies all CoNS by detection of the cns marker. Similarly, the detection of the 16S rRNA in all (100\%) bacteria studied including staphylococcal and non-staphylococcal strains supports the use of this gene as a diagnostic marker for bacteria [43]. Though the use of higher oxacillin concentrations recommended by the CLSI [38, 39] have been reported elsewhere [44], the $0.5 \mathrm{mg} / \mathrm{L}$ oxacillin used in this study supports the recent report of low oxacillinresistant staphylococci (MIC $=0.5 \mathrm{mg} / \mathrm{L})$ in the UK [45]. In view of the variations in gene expression, it has been suggested that mecA-positive staphylococci showing low-level oxacillin-resistance should be regarded as constitutively oxacillin-resistant [3].

The new assay completes cycling within an hour which compares favourably with a recent PVL/MRSA real-time PCR assay [45]. The total turn-around-time was less than 4 hours which also compares favourably with recent end-point PCR assays [41], while the LoD was found to be $1.0 \times 10^{3} \mathrm{CFU} / \mathrm{mL}$ (for $16 S$ rRNA marker) and $1.0 \times 10^{4} \mathrm{CFU} / \mathrm{mL}$ (for the other six markers). These parameters further support the usefulness of the new heptaplex PCR assay in routine clinical diagnosis and infection control.

\section{Conclusion}

Though the absence of $v a n A$ in Nottingham local clinical strains corroborates the vancomycin phenotype, the recent finding of VRSA in Portugal and the report of $46.2 \%$ VRSA in chickens are pointers that the new heptaplex PCR assay will find relevance in routine diagnosis and infection control. Also, the detection of the cns sequence which is unique to CoNS and completely independent of $S$. aureus gene (spa) shows that the new assay will allow microbiology laboratories to easily identify the presence of both CoNS and S. aureus directly in poly-microbial specimens.

\section{Additional files}

Additional file 1: Reference bacterial strains used for validation of the new heptaplex PCR assay. (DOCX $29 \mathrm{~kb}$ )

Additional file 2: Evaluation of the new heptaplex PCR assay on spiked blood cultures. (DOCX $65 \mathrm{~kb}$ )

\section{Competing interests}

The authors declare that they have no competing interests.

\section{Authors' contributions}

CEO conception and design, all the experimentation, analysis and interpretation of data, drafting and revising the manuscript. KGW supervision, analysis and interpretation of data, and revising the manuscript. DPJT supervision, analysis and interpretation of data, and revising the manuscript. AC oversight of work in BSL2+ workspace, instrumentation, biological safety and control, supervision, analysis and interpretation of data, and revising the manuscript. RJ conception, acquisition of funding, analysis and interpretation of data, general supervision of the research group, and revising the manuscript. All authors read and approved the final manuscript.

\section{Acknowledgements}

We thank Dr. Fiona Hamilton for the blood cultures and Dr. Richard Spence for the NARSA and Nottingham clinical staphylococci. CEO thanks the University of Nottingham for funding the experimental work described in this paper and for the partial tuition fee scholarship granted him for his PhD. CEO also thanks the CBS microbiology researchers for the CONS and other bacterial strains.

Received: 14 October 2014 Accepted: 21 July 2015

Published online: 05 August 2015

\section{References}

1. Schleucher RD, Gaessler M, Knobloch J. Panton-Valentine LeukocidinProducing Methicillin-Sensitive Staphylococcus aureus as a Cause for Recurrent, Contagious Skin Infections in Young, Healthy Travelers Returned From a Tropical Country: A New Worldwide Public Health Problem? J Travel Med. 2008;15:137-9.

2. Shallcross LJ, Fragaszy E, Johnson AM, Hayward AC. The role of the PantonValentine leucocidin toxin in staphylococcal disease: a systematic review and meta-analysis. Lancet Infect Dis. 2013;13(1):43-54.

3. Geha DJ, Uhl JR, Gustaferro CA, Persing DH. Multiplex PCR for identification of methicillin-resistant staphylococci in the clinical laboratory. J Clin Microbiol. 1994;32:1768-72

4. Zhang K, Sparling J, Chow BL, Elsayed S, Hussain Z, Church DL, et al. New quadriplex PCR assay for detection of methicillin and mupirocin resistance and simultaneous discrimination of Staphylococcus aureus from coagulasenegative staphylococci. J Clin Microbiol. 2004;42(11):4947-55.

5. McClure JA, Conly JM, Lau V, Elsayed S, Louie T, Hutchins W, et al. Novel multiplex PCR assay for detection of the staphylococcal virulence marker Panton-Valentine leukocidin genes and simultaneous discrimination of methicillin-susceptible from -resistant staphylococci. J Clin Microbiol. 2006;44(3):1141-4.

6. Huletsky A, Giroux R, Rossbach V, Gagnon M, Vaillancourt M, Bernier M, et al New Real-Time PCR Assay for Rapid Detection of Methicillin- Resistant Staphylococcus aureus Directly from Specimens Containing a Mixture of Staphylococci. J Clin Microbiol. 2004;42(5):1875-84.

7. Rossney AS, Herra CM, Brennan Gl, Morgan PM, O'Connell B. Evaluation of the Xpert Methicillin-Resistant Staphylococcus aureus (MRSA) Assay Using the GeneXpert Real-Time PCR Platform for Rapid Detection of MRSA from Screening Specimens. J Clin Microbiol. 2008;46(10):3285-90.

8. Bartels MD, Boye K, Rohde SM, Larsen AR, Torfs H, Bouchy P, et al. A common variant of staphylococcal cassette chromosome mec type IVa in isolates from Copenhagen, Denmark, is not detected by the BD GeneOhm methicillin-resistant Staphylococcus aureus assay. J Clin Microbiol. 2009;47:1524-7.

9. Martineau F, Picard FJ, Ke D, Paradis S, Roy PH, Ouellette M, et al. Development of a PCR Assay for Identification of Staphylococci at Genus and Species Levels. J Clin Microbiol. 2001;39:2541-7.

10. Hirotaki S, Sasaki T, Kuwahara-Arai K, Hiramatsu K. Rapid and accurate identification of human-associated staphylococci by use of multiplex PCR. J Clin Microbiol. 2011;49(10):3627-31.

11. Sasaki T, Tsubakishita S, Tanaka Y, Sakusabe A, Ohtsuka M, Hirotaki S, et al. Multiplex-PCR method for species identification of coagulase-positive staphylococci. J Clin Microbiol. 2010;48(3):765-9.

12. Patrick CC. Coagulase-negative staphylococci: pathogens with increasing clinical significance. J Pediatr. 1990;116(4):497-507. 
13. von Eiff C, Proctor RA, Peters G. Coagulase-negative staphylococci. Pathogens have major role in nosocomial infections. Postgrad Med. 2001;110(4):63-4.

14. Zhang K, McClure JA, Elsayed S, Louie T, Conly JM. Novel Multiplex PCR Assay for Simultaneous Identification of Community-Associated Methicillin-Resistant Staphylococcus aureus Strains USA300 and USA400 and Detection of mecA and Panton-Valentine leukocidin Genes, with Discrimination of Staphylococcus aureus from Coagulase-Negative Staphylococci. J Clin Microbiol. 2008;46:1118-22.

15. Kobayashi SD, Musser JM, DeLeo FR. Genomic analysis of the emergence of vancomycin-resistant Staphylococcus aureus. MBio. 2012;3(4):e00170-212.

16. Zhu W, Clark N, Patel JB. pSK41-like plasmid is necessary for Inc18-like vanA plasmid transfer from Enterococcus faecalis to Staphylococcus aureus in vitro. Antimicrob Agents Chemother. 2013;57(1):212-9.

17. Friães A, Resina C, Manuel V, Lito L, Ramirez M, Melo-Cristino J. Epidemiological survey of the first case of vancomycin-resistant Staphylococcus aureus infection in Europe. Epidemiol Infect. 2014;5:1-4.

18. Kos VN, Desjardins CA, Griggs A, Cerqueira G, Van Tonder A, Holden MT, et al. Comparative genomics of vancomycin-resistant Staphylococcus aureus strains and their positions within the clade most commonly associated with Methicillin-resistant S. aureus hospital-acquired infection in the United States. MBio. 2012;3(3):e00112-212. doi:10.1128/mBio.00112-12.

19. Rossi F, Diaz L, Wollam A, Panesso D, Zhou Y, Rincon S, et al. Transferable vancomycin resistance in a community-associated MRSA lineage. N Engl J Med. 2014;370(16):1524-31.

20. Shibabaw A, Abebe T, Mihret A. Antimicrobial susceptibility pattern of nasal Staphylococcus aureus among Dessie Referral Hospital health care workers, Dessie, Northeast Ethiopia. Int J Infect Dis. 2014;12(14):01480-5.

21. Otalu Jr O, Kabir J, Okolocha EC, Umoh VJ. Multi-drug Resistant Coagulase Positive Staphylococcus aureus from Live and Slaughtered Chickens in Zaria, Nigeria. Int J Poult Sci. 2011;10(11):871-5.

22. Molenkamp R, VanDer HA, Schinkel J, Beld M. Simultaneous detection of five different DNA targets by real-time Taqman PCR using the Roche LightCycler480: Application in viral molecular diagnostics. J Virol Methods. 2007;141:205-11.

23. Spence RP, Wright $V$, Ala-Aldeen DA, Turner DP, Wooldridge KG, James $R$. Validation of Virulence and Epidemiology DNA Microarray for Identification and Characterization of Staphylococcus aureus Isolates. J Clin Microbiol. 2008;46:1620-7.

24. Okolie CE: Development of Diagnostic and Therapeutic Tools for Staphylococcus aureus infections. PhD Thesis. University of Nottingham, School of Molecular Medical Sciences; 2009. Available at the British Library (http://ethos.bl.uk/OrderDetails.do?uin=uk.bl.ethos.517830) or from the author

25. Louie L, Goodfellow J, Mathieu P, Glatt A, Louie M, Simor AE. Rapid Detection of Methicillin-Resistant Staphylococci from Blood Culture Bottles by Using a Multiplex PCR Assay. J Clin Microbiol. 2002;40(8):2786-90

26. Nakagawa S, Taneike I, Mimura D, Iwakura N, Nakayama T, Emura T, et al. Gene sequences and specific detection for Panton-Valentine leukocidin. Biochem Biophys Res Commun. 2005;328:995-1002.

27. Okolie CE, Wooldridge KG, Turner DP, Cockayne A, James R: Development of a new pentaplex real-time $P C R$ assay for the identification of poly-microbial specimens containing Staphylococcus aureus and other staphylococci with simultaneous detection of staphylococcal virulence and methicillin resistance markers. Molecular and Cellular Probes, 2015:29(3):144-50. DOI: 10.1016/ j.mcp.2015.03.002

28. Al-Talib H, Yean CY, Al-Khateeb A, Hassan H, Singh KK, Al-Jashamy K, et al. A pentaplex PCR assay for the rapid detection of methicillin-resistant Staphylococcus aureus and Panton-Valentine Leucocidin. BMC Microbiol. 2009;9:113-20

29. Okolie CE, Cockayne A, Wooldridge K, James R. Development and validation of a new diagnostic PCR assay for vanA gene encoding vancomycin resistance in Staphylococcus aureus. IJAMBR. 2014;2:1-10.

30. Hwang SM, Kim MS, Park KU, Song J, Kim E-C. tuf Gene Sequence Analysis Has Greater Discriminatory Power than 16S rRNA Sequence Analysis in Identification of Clinical Isolates of Coagulase-Negative Staphylococci. J Clin Microbiol. 2011:49(12):4142-9.

31. Clifford RJ, Milillo M, Prestwood J, Quintero R, Zurawski DV, Kwak Yl, et al Detection of Bacterial 165 rRNA and Identification of Four Clinically Important Bacteria by Real-Time PCR. PLoS One. 2012;7(11):e48558. doi:10.1371/journal.pone.0048558
32. Matsuda K, Iwaki KK, Garcia-Gomez J, Hoffman J, Inderlied CB, Mason WH, et al. Bacterial Identification by 165 rRNA Gene PCR-Hybridization as a Supplement to Negative Culture Results. J Clin Microbiol. 2011:49(5):2031-4

33. McPherson MJ, Moller SG. PCR. Oxford: Taylor \& Francis Group; 2006

34. Roux KH: Optimization and troubleshooting in PCR. Cold Spring Harb Protoc 2009, doi:10.1101/pdb.ip66.

35. Stepanović S, Hauschild T, Dakić I, Al-Doori Z, Švabić-Vlahović M, Ranin L, et al. Evaluation of Phenotypic and Molecular Methods for Detection of Oxacillin Resistance in Members of the Staphylococcus sciuri Group. J Clin Microbiol. 2006:44(3):934-7.

36. Oliveira AD, d'Azevedo PA, de Sousa LB, Viana-Niero C, Francisco W Lottenberg C, et al. Laboratory detection methods for methicillin resistance in coagulase negative Staphylococcus isolated from ophthalmic infections. Arg Bras Oftalmol. 2007;70(4):667-75.

37. Clinical and Laboratory Standards Institute. Methods for dilution antimicrobial susceptibility tests for bacteria that grow aerobically. Approved standard. 9th ed. Wayne, PA: CLSI; 2012. CLSI document M07-A9.

38. Clinical and Laboratory Standards Institute. Performance Standards for Antimicrobial Susceptibility Testing: 22nd Informational Supplement CLS M100-S22. Wayne, PA: CLSI; 2012.

39. Clinical and Laboratory Standards Institute: Performance Standards for Antimicrobial Disk Susceptibility Tests; Approved Standard-Eleventh Edition. CLSI document M02-A11. PA: Wayne; 2012.

40. Loonen AJ, Jansz AR, Kreeftenberg H, Bruggeman CA, Wolffs PF, van den Brule AJ. Acceleration of the direct identification of Staphylococcus aureus versus coagulase-negative staphylococci from blood culture material: a comparison of six bacterial DNA extraction methods. Eur J Clin Microbiol Infect Dis. 2011;30(3):337-3342.

41. Clinical and Laboratory Standards Institute. Molecular Diagnostic Methods for Infectious Diseases. Approved Guideline. Second Editionth ed. Wayne, PA: Clinical and Laboratory Standards Institute; 2010. Document MM06-A2.

42. Panda S, Kar S, Choudhury R, Sharma S, Singh DV. Development and evaluation of hexaplex PCR for rapid detection of methicillin, cadmium/zinc and antiseptic resistant staphylococci, with simultaneous identification of PVL-positive and-negative Staphylococcus aureus and coagulase negative staphylococci. FEMS Microbiol Lett. 2014:352(1):114-22.

43. Guembe M, Marín M, Martín-Rabadán P, Echenagusia A, Camúñez F, Rodríguez-Rosales G. Use of Universal 16SrRNA Gene PCR as a Diagnostic Tool for Venous Access Port-Related Bloodstream Infections. J Clin Microbiol. 2013;51(3):799-804.

44. Campana EH, Carvalhaes CG, Nonato B, Machado AM, Gales AC. Comparison of M.I.C.E. and Etest with CLSI Agar Dilution for Antimicrobial Susceptibility Testing against Oxacillin-Resistant Staphylococcus spp. PLoS One 2014, DOl:10.1371/journal.pone.0094627.

45. Pichon B, Hill R, Laurent F, Larsen AR, Skov RL, Holmes $M$, et al. Development of a real-time quadruplex PCR assay for simultaneous detection of nuc, Panton-Valentine leucocidin (PVL), mecA and homologue mecALGA251. J Antimicrob Chemother. 2012;67:2338-41.

\section{Submit your next manuscript to BioMed Central and take full advantage of:}

- Convenient online submission

- Thorough peer review

- No space constraints or color figure charges

- Immediate publication on acceptance

- Inclusion in PubMed, CAS, Scopus and Google Scholar

- Research which is freely available for redistribution 